\title{
Developing the Social Empathy Index: An Exploratory Factor Analysis
}

\author{
Elizabeth A. Segal \\ M. Alex Wagaman \\ Karen E. Gerdes
}

\begin{abstract}
Social empathy, the ability to understand people from different socioeconomic classes and racial/ethnic backgrounds, with insight into the context of institutionalized inequalities and disparities, can inspire positive societal change and promote social wellbeing. The value of teaching social empathy and creating interventions that promote social empathy is enhanced by the ability to measure and assess it. This article provides a validation of the Social Empathy Index, a tool that practitioners can easily use to assess individuals' levels of interpersonal and social empathy. An exploratory factor analysis was used to validate the instrument and confirm the conceptual model for social empathy.
\end{abstract}

Keywords: Social empathy, individual empathy, social change, instrument validation

\section{INTRODUCTION}

In a community lecture in 2004, Robert Reich, the former Secretary of Labor, shared his insights regarding times when empathy and social caring transformed society, such as the civil rights movement in the 1960s. He viewed these points in time as few and far between. Reich called for an enlightened self-interest to create more of these times but he did not define what he meant nor did he explain to the crowd how enlightened selfinterest could be cultivated. Similarly, in The Audacity of Hope (2006) President Obama wrote about the importance of empathy. Referring to his colleague Senator Paul Simon, Obama wrote, "That last aspect of Paul's character-a sense of empathy - is one that I find myself appreciating more and more as I get older. It is at the heart of my moral code, and it is how I understand the Golden Rule-not simply as a call to sympathy or charity, but as something more demanding, a call to stand in somebody else's shoes and see through their eyes” (p. 66). What would social policies look like if citizens demanded that they be created by policymakers who could see the world through the eyes of the people who would be most impacted? Reich and Obama were both describing a compassionate society with an intense, shared insight into the lives of others. The authors refer to the mechanism that enables such a society as social empathy.

Social empathy is the ability to genuinely understand people from different socioeconomic classes and racial/ethnic backgrounds within the context of institutionalized inequalities and disparities (Segal, 2011). Social empathy insights can inspire positive societal change and promote social well-being through the use of democratic processes, social tolerance, and civic engagement (Morrell, 2010). More than a decade ago, Hoffman (2000) recognized the broader social dimensions of empathy when he called for expanding the teaching of empathy to create a moral and just society

Elizabeth A. Segal, Ph.D., is a Professor, M. Alex Wagaman, MSW, is a Doctoral Candidate, and Karen E. Gerdes, Ph.D. is an Associate Professor, all in the College of Public Programs, School of Social Work, Arizona State University in Phoenix.

Copyright (C) 2012 Advances in Social Work Vol. 13 No. 3 (Fall 2012), 541-560 
by going beyond individual empathy. He wanted to teach children how to "extend empathy to other groups, so that children will be more aware of the impact of their actions on others who differ from them in obvious ways” (p. 294).

Social work, psychology, anthropology, evolutionary biology, social cognitive neuroscience, as well as many other disciplines, have all acknowledged the value of interpersonal empathy (de Waal, 2009; Decety, 2011; Gibbons, 2011). However, very little has been written about social empathy or how to measure it. This article articulates a conceptualization of social empathy and reports on the development of a social empathy index (SEI). In addition to measuring an individual's level of social empathy, the SEI has the potential to aid social workers in cultivating and promoting social empathy.

\section{The Value of Interpersonal Empathy}

Empathy is the ability to understand what other people are feeling and thinking and it is an essential skill in facilitating social agreement and successfully navigating personal relationships (de Waal, 2009). It is critical to our survival because it requires the accurate perception, interpretation, and response to the emotional signals of others (Preston \& de Waal, 2002). Therefore, empathy is a key building block for prosocial behavior, or the actions people take that benefit others and society (Eisenberg \& Mussen, 1989). There is substantial research evidence that empathy is important in the development of healthy relationships (Toussaint \& Webb, 2005); it supplies the affective and motivational foundation for moral development (Eisenberg \& Eggums, 2009; Smetana \& Killen, 2008); and promotes helping and prosocial behaviors particularly during adolescence (Batson, Chang, Orr, \& Rowland, 2002; Batson, Håkansson Eklund, Chermok, Hoyt, \& Ortiz, 2007; McMahon, Wernsman, \& Parnes, 2006). For youth, higher levels of empathy are associated with increased conflict resolution (de Weid, Branje, \& Meeus, 2007) and willingness to come to the defense of a bullied peer (Gini, Albiero, Benelli, \& Altoe, 2007). Parental empathy has been cited as crucial for raising healthy children (CurtnerSmith et al., 2006) and partner empathy is cited as a key attribute in satisfying relationships (Busby \& Gardner, 2008).

The absence of empathy can lead to destructive behaviors and adversely affect relationships. A lack of interpersonal empathy is associated with narcissism, bullying, violent crime, abusive parenting, spousal battering, and sexual offending (Covell, Huss, \& Langhinrichsen-Rohling, 2007; Elsegood \& Duff, 2010; Gini, Albieri, Benelli, \& Altoe, 2008; Joliffe \& Farrington, 2004; Ritter et al., 2011). In spite of so much compelling research on the value of empathy, definitions and conceptualizations vary greatly. The diversity of definitions and measurement devices makes comparisons between empathy studies challenging (Gerdes, 2011; Gerdes, Segal, \& Lietz, 2010).

\section{What is Missing? Understanding Empathy and the Impact on Society}

How does empathy play a role in the larger societal realm? Is it a collection of individual levels of empathy, or is there a broader way to conceptualize the impact and influence of social empathy? A critical piece in understanding the macro impact of empathy is to consider context. For example, a great deal of research has been conducted 
on the phenomenon of bullying, raising concerns about the social interactions of youth and the lack of empathy. Some researchers argue that school bullying is a social phenomenon that reflects power relations in certain contexts rather than just individuals with aggressive or "evil" behaviors (Horton, 2011). In this example, understanding the broader social context of schools as well as the barriers to child development can provide greater insight into why empathic behaviors may be absent in social settings. This can be particularly damaging on a societal level.

In a macro context, racism, sexism, and homophobia are behaviors that not only diminish the humanity of marginalized groups, but those committing such behaviors "lose sensitivity to those who are hurt; they become hard, cold, and unfeeling to the plight of the oppressed; and they turn off their compassion and empathy for others" (Sue, 2010, p. 130). This process has been part of history. Glick (2008) describes this phenomenon as "ideological scapegoating." Complex and difficult social, economic, and political situations can lead to social constructions based in stereotyping to understand complex situations and deal with the fear of misunderstood social events. Fear is a trigger that can hijack the more complicated and involved cognitive processing of empathy (O’Connor, Berry, Weiss, \& Gilbert, 2002). The extreme outcome of this phenomenon is that majority groups, lacking empathic accuracy and feeling fearful of changing social conditions, can become so unfeeling of those different than them that socially harmful behaviors such as slavery, apartheid, and genocide can become sanctioned and institutionalized (Glick, 2002, 2005, 2008).

In 1995, Robert D. Putnam published his article Bowling Alone: America's Declining Social Capital (with a best-selling book on the subject five years later) in which he famously bemoaned the decline in civil engagement and membership in social groups. This decline meant people were more out of touch with others, with negative social outcomes. Twenge (2006) captured public attention with her research on young people's sense of entitlement and increased narcissism. Twenge and Campbell (2009) later codified the concept of a "narcissism epidemic." The authors argue that the increase in narcissism is accompanied by a decline in warm and caring relationships and empathy. Recently, Konrath, O'Brien, and Hsing (2011) compared scores of college students on a common (although outdated) empathy measure and found a decline in scores over the past 30 years. Headlines from newspapers that picked up the research heralded that young people today are less empathic than young people of thirty years ago. Less pessimistic is Rifkin's (2009) review of empathy throughout history. He argues that we are on the opposite track and empathy has increased over time, but he warns that we are at a critical juncture in the history of our civilization and could see a backsliding of empathic concern. These social phenomena and research findings suggest a need to better understand empathy in the context of social relations, as well as the need to measure and assess levels of social empathy. The current research study applied rigorous scientific testing informed by professional values and practice experience in an effort to develop the Social Empathy Index. 


\section{What is Social Empathy?}

Social empathy is the "ability to understand people by perceiving or experiencing their life situations and as a result gain insight into structural inequalities and disparities" (Segal, 2011, pp. 266-7). The assumption upon which the concept of social empathy is built is that with socially empathic feelings and knowledge, people are more inclined to work to promote social and economic justice and social well-being (Segal, 2007, 2008). Engaging in social empathy requires people to see themselves in relation to the outside world, and may increase their sense of efficacy or impact on the outside world, and ultimately gain a sense of empowerment (Wagaman, 2011). It is hoped that the development of social empathy can increase social engagement while promoting an individual's own empathic abilities. Greater social engagement helps a person develop as a member of the larger society and in turn creates community, cultivates democratic behaviors, and protects public interests (Putnam, 1993). Promoting social empathy has the potential to enhance social engagement, improve prosocial processes, and build better social policies and programs, all of which benefit both the individual and society.

\section{DEVELOPMENT OF THE SOCIAL EMPATHY INDEX}

The SEI was constructed using the model of social empathy outlined in Segal (2011). The model identifies three components-interpersonal empathy, contextual understanding, and social responsibility. The model also makes the assumption that if all three of these components are engaged, the result will be actions that promote social justice (see Figure 1). The conceptual framework posits that interpersonal or general empathy is the crucial underlying foundation upon which the larger perspective of social empathy can be built. For this reason the SEI includes the 20-item Empathy Assessment Index (Gerdes, Lietz, \& Segal, 2011), a measure of interpersonal or general empathy.

\section{Figure 1}

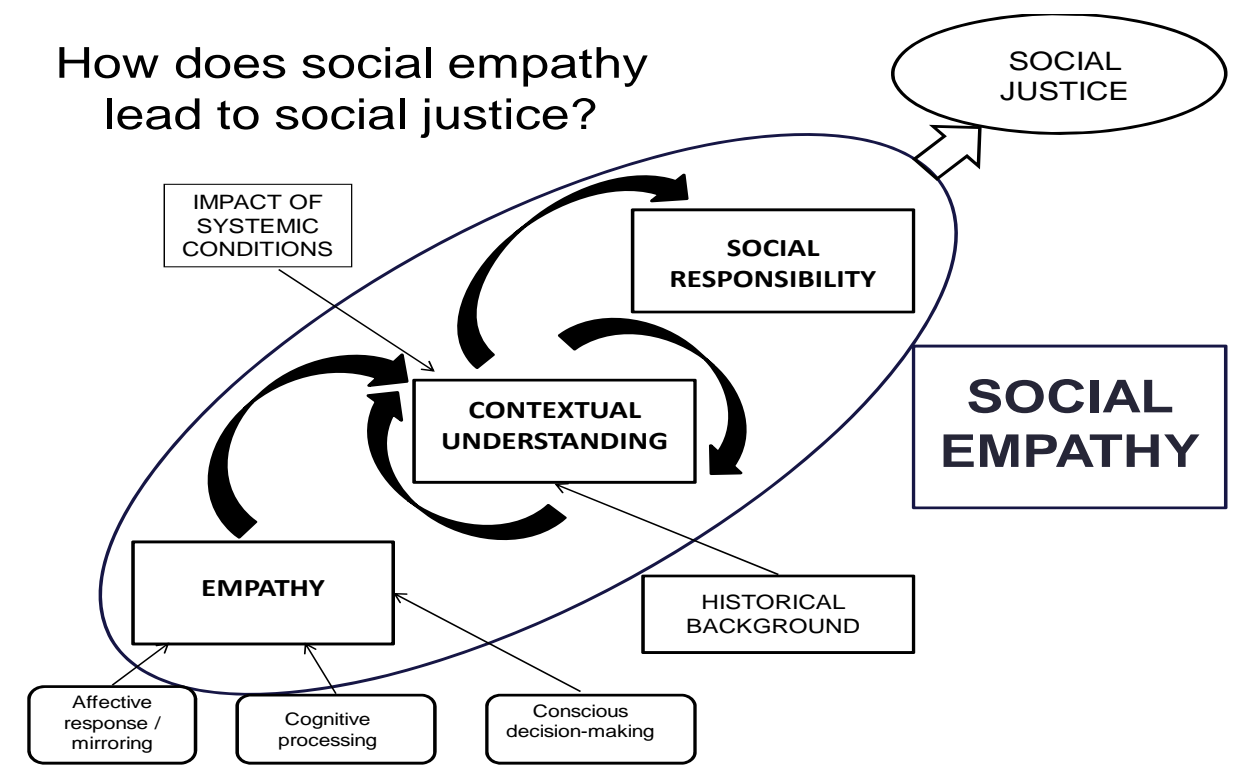




\section{Interpersonal Empathy}

The Empathy Assessment Index (EAI) (Gerdes et al., 2011; Gerdes, Segal, \& Lietz, 2010; Lietz et al., 2011) is a critical and foundational part of the Social Empathy Index. The 20-item EAI has four components based on the most recent social cognitive neuroscience conceptualization of empathy: 1) affective response, 2) self-other awareness, 3) perspective-taking, and 4) emotion regulation. (Decety \& Moriguchi, 2007) The four components represent the four isolable neural networks that mediate empathy in the brain. These networks process incoming information on a millisecond timescale allowing individuals to feel what others feel, perceive what others see or understand, and possibly even recognize the intentions of others (Mar, 2011).

The affective response component represents the affective resonance the perceiver experiences when observing the target's affective state. Shared representations through the mechanisms of perception-action coupling (Preston \& de Waal, 2002) and simulation (Goldman, 2006) mediate the experience of affective empathy. Affective empathy is often referred to as mirroring, and occurs on an unconscious level. As such, it requires some amount of self-other awareness and perspective-taking in order to distinguish the true experience of empathy from emotional contagion or simple mimicry (Walter, 2012). Self-other awareness and perspective-taking are cognitive processes that move us from physically sharing an affective response to viewing what that response might mean for the other person. Emotion regulation, the fourth component, supports and enables the process of empathizing with another person while preventing the affective response from turning into an experience of personal distress (Decety, 2011).

\section{Contextual Understanding}

Interpersonal empathy is often limited without an accurate assessment of context (Singer \& Lamm, 2009). The degree to which people can empathize across cultures requires processing information contextually: "we need to identify and analyze more precisely and systematically the variety of cultural frameworks, social situations, and political-economic conditions that tend to either suppress and inhibit basic empathy or amplify it into a frequent and reliable means of knowing” (Hollan, 2012, p. 76). Thus, social empathy examines context and includes insight into the structural inequalities that may impact others' lives, different from our own.

A key skill that is part of contextual understanding is the ability to take the perspective of those who are in different life situations. Perspective-taking on the individual level is included in the EAI. But perspective-taking on a macro level is key to contextual understanding. Such macro-perspective-taking can improve social relations by decreasing prejudice and stereotyping as well improving social coordination (Galinsky, $\mathrm{Ku}, \&$ Wang, 2005). The United States Army recognized the need for its military personnel to become skilled in perspective-taking because of the need to bridge cultural gaps between U.S. soldiers and populations in the regions of operations. Reflecting a macro viewpoint, the U.S. military focuses on "social perspective-taking." "Performed correctly, SPT allows the soldier to accurately consider the host-national's perspective without cultural bias and erroneous assumptions” (Roan et al., 2009, p. v). The report 
goes on to cite that the value of SPT includes the development of social understanding, improved intergroup relations, greater cooperation, and can lead to trust, respect, and good relations. Therefore, the SEI incorporated items to measure macro-perspectivetaking.

While macro-perspective-taking can increase people's perceptions of commonalities between their own identity group and other different groups, it may mask or reduce understanding of intergroup inequalities (Todd, Bodenhausen, Richeson, \& Galinsky, 2011). Dovidio, Gartner, and Saguy (2009) found that increasing perspective-taking abilities can improve understanding of groups' commonalities and reduce prejudice, but inadvertently it may also lead to an underestimation of intergroup inequalities. This lack of understanding of inequalities between groups would be a deterrent to efforts for social change. Thus, macro-perspective-taking is important, but alone cannot enhance social empathy.

Macro-perspective-taking needs to be coupled with contextual understanding. "The role of context therefore is a significant component of perspective taking, since an individual will need to consider all the factors when hypothesizing about the perspective of another person," which is especially true when dealing with other cultures (Roan et al., 2009, p. 4). In order to fully understand the life circumstances of different groups, examination of historical events and the place of group membership in society at-large are critical. For example, when viewing the experiences of different racial groups, macroperspective-taking involves the ability to imagine what life is like as a member of that racial group. In addition, historical events that have been brought to bear on that particular racial group must be understood. Finally, how other groups in society view membership in that particular racial group must be examined. Thus, the items developed to address contextual understanding included elements that would help to identify levels of macro-perspective-taking and macro-self-other awareness, that is, considering what the life experiences are of others from different social and economic backgrounds. When these skills are used, a better understanding of the societal context of inequality and the structural barriers that inhibit opportunity for some groups is achieved.

\section{Social Responsibility}

When accurate empathic insight into other people's lives is gained, it is often followed by a sense of social responsibility (Frank, 2001). Because the impetus behind social empathy is to gain insights into the lives of others in order to create policies that address social concerns, the model assumes that a commitment to social responsibility accompanies social empathy. Hoffman (2000) explains this relationship:

If one thinks about how society's resources should be distributed, one might focus on the implications of different distributive systems for oneself or for others. A self-serving perspective will lead one to prefer principles that coincide with one's own condition: A high producer would choose output, competence, or effort and a low producer would choose need or equality. An empathic perspective, on the other hand, would lead one to take the welfare of others into account...[and] that leads one to imagine the consequences of different systems 
for society's least advantaged people or for people who work hard (Hoffman, 2000, pp. 230-231).

Using terms of the newer neuroscience, Hoffman is describing perspective-taking and self-other awareness on a societal level leading to a sense of social responsibility. For the SEI, measuring social responsibility was challenging. People may report a strong sense of responsibility, but whether they actually behave in that way is much more difficult to assess. In a self-report instrument, we decided that the best way to measure social responsibility was constructed through two types of questions, ones that identified beliefs related to social responsibility and ones that related to behaviors that correspond to social responsibility, which in the model are assumed to lead to social justice. The SEI was therefore constructed with items designed to assess interpersonal empathy (using the 20 item EAI), contextual understanding, social responsibility, and social justice.

\section{METHODS}

\section{Item Generation}

Given the development of the EAI (Empathy Assessment Index) and its validation in previous studies, the research team agreed that it fully captured general interpersonal empathy as conceptualized in the larger social empathy model, and assumed its inclusion in the final SEI. Therefore, the researchers worked only to develop an item pool for the remaining constructs. Item generation for contextual understanding and social responsibility was based on the conceptualizations described above.

Content validity was addressed by constructing items that logically or theoretically connected to our conceptualizations (Sartori \& Pasini, 2007). For example, contextual understanding items included asking about whether there are barriers such as lack of opportunities or discrimination that prevent some groups from succeeding in the United States, why people are homeless, and the importance of taking into consideration the political perspectives of other people even if we don't agree with them. Social responsibility items reflected beliefs in government involvement in social welfare, community service, and voting. Social justice was constructed with items that asked about actions that people believed were important such as helping a person from a different race or ethnicity, helping people worse off, and taking action to help others (a full listing of all the items can be found in Appendix A).

Once a pool of items was generated, they were reviewed by team members for face validity and pre-tested with a group of graduate social work students who then discussed the items after the pre-test. On the basis of the feedback within the research team and from the pre-test, items were edited for wording and comprehension.

The result was a pool of thirty-eight items using the same 6-point Likert scale (1=“never”, 2="rarely”, 3="sometimes”, 4="frequently”, 5=“almost always”, $6=$ "always") as the EAI, grouped into the three general concepts discussed above. The contextual understanding component consisted of thirteen items, two of which were reverse-scored. The social responsibility subscale consisted of thirteen items. And the social justice subscale consisted of twelve items, one of which was reverse-scored. 


\section{Item Testing}

The 38 SEI items were combined with the 20-item EAI creating a 58 item instrument. The EAI items were presented first, with the SEI items presented next in random order. As previously mentioned, all 58 items used the same 6-point Likert scale. Items were prefaced with the statement, "Please respond to the following questions by selecting the choice that most closely reflects your feelings or beliefs.” The 58 items were loaded into Qualtrics, an online survey software program.

\section{Participants}

Based on the 58 items in the SEI and the intended analysis plan, a sample of 300 participants was sought (Costello \& Osborne, 2005). Participants were recruited for the study, as approved by the University's Institutional Review Board, from six BSW-level classes and one MSW-level class. Participation was voluntary and in some classes extra credit was offered. Participants were provided a hyperlink to the survey, which was referred to as a "human relations survey" to minimize social desirability, and were instructed to complete the self-report questionnaire within 72 hours. All responses were anonymous.

A total of 315 students started the survey process. Fourteen students had missing data and were excluded from the analysis (4.4\%). The final sample size consisted of 301 respondents whose ages ranged from 18 to $59(M=23.8, S D=7.8)$. Seventy-four percent of the sample was female $(n=224), 24 \%(n=71)$ were male and $2 \%(n=6)$ either reported other gender or did not report gender. Of those who reported their ethnicity, 53\% were Caucasian ( $n=157), 26.6 \%$ were Latino $(n=79), 5.4 \%$ were African Americans $(n$ $=16$ ), and $3 \%$ were American Indian $(n=9)$. Nearly $24 \%$ were freshman $(n=70), 20 \%$ were sophomores $(n=59), 27 \%$ were juniors $(n=80), 10.5 \%$ were seniors $(n=31)$, and $18.3 \%$ were first-year Master of Social Work students $(n=54)$. Just over $40 \%(n=120)$ of the study participants described their families growing up as "poor" or "working class", with another $40 \%$ describing their family growing up as "middle class". Fortyfour percent $(n=131)$ of the sample identified as social work majors followed by criminal justice at $27 \%(n=79)$. Just over half of the sample $(54.5 \%)$ reported being employed at the time of the survey.

\section{Approach to Analysis}

Descriptive statistics, zero-order correlations, subscale reliability analysis, and principal components analysis were used for item reduction. Once reduced, resulting items were analyzed using exploratory factor analysis. Although an a priori theoretical model existed at the time of data collection, a confirmatory factor analysis was not the most appropriate analysis for the data because of the high levels of collinearity between the self-other awareness and perspective-taking items of the EAI with SEI items. Given this, and the lack of available theoretical guidance in the literature for conceptualizing and measuring the components of social empathy, an exploratory factor analysis was conducted. Once a final model was obtained, estimates of subscale reliability were obtained using the newly theorized subscales. Finally, EAI component mean score and 
SEI component mean score correlations were assessed for possible conceptual overlap or collinearity.

\section{RESULTS}

As indicated in Appendix A, all of the items had means above the mid-point of the response scale. Very few responses of "never" or "rarely" were found for any of the items, with only seven items (Q27, Q28, Q29, Q31, Q32, Q33, Q35) having more than $10 \%$ of responses falling within these two response categories. The overall negatively skewed mean scores may be due, in part, to both the self-report nature of the instrument and the sample selection, most of which were in human relations-based majors.

\section{Item Reduction}

First round of analysis. Item reduction activities based on a priori theory about social empathy began with subscale reliability analysis. Table 1 summarizes the reliability coefficients, and identifies items that would increase the subscale reliability if deleted. All three subscales, as originally theorized, had high reliability, and few items that significantly impacted the overall reliability. Further analysis that included examination of zero-order correlations between items, and correlations between items and their intended subscale mean scores provided further evidence supporting deletion of the four items identified in the reliability analysis, as well as others that appeared to be problematic.

The third and final step in the first round of item reduction included principal components analysis (not shown here). Principal components analysis (PCA) is often appropriate for data driven item reduction because it results in uncorrelated composites of the variance in the items rather than identification of latent variables "PCA is intended to simply summarize many variables into fewer components, and the latent constructs (i.e., factors) are not the focus of the analysis" (Henson \& Roberts, 2006, p. 398). These analyses resulted in the elimination of 17 of the original 38 SEI items (see Appendix A).

Table 1: $\quad$ Subscale Reliability Analysis of Items as Originally Theorized

\begin{tabular}{lllll}
\hline Subscale & $\begin{array}{l}\text { Reliability } \\
\text { Coefficient }\end{array}$ & \multicolumn{1}{l}{ M } & \multicolumn{1}{c}{$\boldsymbol{S D}$} & Items, if deleted, increase $\boldsymbol{\alpha}$ \\
\hline Contextual understanding (13 items) & 0.794 & 53.74 & 8.14 & item 27 (.818); item 31 (.819) \\
Social responsibility (13 items) & 0.910 & 59.27 & 10.99 & item 37 (.914) \\
Social justice (12 items) & 0.857 & 55.58 & 8.52 & item 35 (.878) \\
\hline
\end{tabular}

Factor analysis. Based on a priori theoretical understanding of social empathy, its components, and its relationship to empathy, the remaining items were hypothesized to be related to two, rather than three, underlying factors - contextual understanding of systemic barriers and macro level self-other awareness and perspective-taking. An exploratory factor analysis was conducted in SPSS on the remaining twenty-one items using principal axis factoring (PAF) with an oblique rotation (oblimin, delta $=.4$ ) retaining two factors based on a priori theory. PAF was selected as the most appropriate 
method based on the theoretical assumption that common variance among the items in each subscale can be accounted for by latent constructs, and that these constructs are correlated (Costello, \& Osborne, 2005; Pett, Lackey, \& Sullivan, 2003). With a sample size of 301, the subject-to-item ratio was just under 8:1.

Three additional items were subsequently eliminated based on low loadings and/or cross-loadings. Elimination of these items was affirmed through expert review by a leading scholar in the area of empathy. Theoretically, the items appeared to fit well with the original constructs (e.g., "I think paying taxes is part of being a good citizen." as a measure of social responsibility) but no longer were theoretically appropriate within the newly theorized constructs of contextual understanding of systemic barriers and macro self-other awareness/perspective-taking.

A second exploratory factor analysis using PAF and an oblique rotation (oblimin, delta $=.4$ ) was conducted on the remaining 18 items. Oblique rotation was selected based on an expectation that the factors would be correlated. Visual interpretation of the scree plot as well as a parallel analysis were conducted. Based on the scree plot and the $95^{\text {th }}$ percentile eigenvalues from random data, two factors were retained. The two factors had eigenvalues of 8.13 and 1.29 which accounted for $52.34 \%$ of the explained variance. After rotation, nine items loaded on each of the two factors with loadings ranging from .5 to .9 (see Table 2). The two factors were correlated at .75. A subsequent reliability analysis on the SEI indicated excellent internal consistency for both the contextual understanding subscale (.88) and macro SOA/PT subscale (.87).

\section{Relationship with EAI Items}

As previously mentioned, initial analysis found significant collinearity between selfother awareness (SOA) and perspective-taking (PT) items in the EAI and items in the original SEI pool. Theoretically, the authors found that this made sense conceptually and reconfigured the components of the SEI to include a factor that measures macro SOA and PT. In order to ensure that the EAI subscales and the SEI subscales are not redundant either conceptually or statistically, correlations were run between all 6 subscales as well as between the overall EAI mean scores. The results can be found in Table 3. As is shown, moderate correlations indicate relationships between the subscales but suggest that each subscale is, in fact, capturing distinct concepts. The social empathy subscale mean scores for contextual understanding of systemic barriers and macro SOA/PT are correlated at .74 $(p<.05)$. 
Table 2: $\quad$ Exploratory Factor Analysis of 18-item Social Empathy Index (SEI): Factor Loadings from the Pattern Matrix after Oblique Rotation

\begin{tabular}{ccc}
\hline $\begin{array}{c}\text { Item } \\
\text { (see Appendix A) }\end{array}$ & $\begin{array}{c}\text { Factor 1: Contextual } \\
\text { Understanding of Systemic } \\
\text { Barriers }\end{array}$ & $\begin{array}{c}\text { Factor 2: Macro Self Other } \\
\text { Awareness and Perspective Taking }\end{array}$ \\
\hline Q21 & .47 & .10 \\
Q39 & .61 & .11 \\
Q49 & .54 & .04 \\
Q25 & .64 & .06 \\
Q47 & .54 & .21 \\
Q53 & .75 & -.14 \\
Q52 & .64 & .12 \\
Q54 & .73 & .05 \\
Q55 & .79 & -.04 \\
Q33 & .19 & .54 \\
Q45 & .17 & .58 \\
Q50 & .05 & .63 \\
Q34 & .15 & .60 \\
Q48 & .03 & .56 \\
Q24 & .24 & .50 \\
Q28 & -.03 & .60 \\
Q40 & -.08 & .67 \\
Q42 & -.04 & .71 \\
\hline
\end{tabular}

Table 3: $\quad$ Correlations between EAI and SEI Components and Total EAI Scores

\begin{tabular}{lcccccc}
\hline Scale/Component & $\begin{array}{c}\text { Emotion } \\
\text { regulation }\end{array}$ & $\begin{array}{c}\text { Affect } \\
\text { sharing }\end{array}$ & $\begin{array}{c}\text { Perspective } \\
\text { taking }\end{array}$ & EAI & $\begin{array}{c}\text { Contextual } \\
\text { understanding }\end{array}$ & $\begin{array}{c}\text { Macro } \\
\text { SOA/PT }\end{array}$ \\
\hline $\begin{array}{l}\text { Self-other awareness } \\
\text { (EAI) - alpha }=.64\end{array}$ & $.42^{* *}$ & $.55^{* *}$ & $.65^{* *}$ & $.84^{* *}$ & $.36^{* *}$ & $.50^{* *}$ \\
$\begin{array}{l}\text { Emotion regulation } \\
\text { (EAI) - alpha }=.68\end{array}$ & & $.22^{* *}$ & $.35^{* *}$ & $.66^{* *}$ & $.14^{*}$ & $.23^{* *}$ \\
$\begin{array}{l}\text { Affect sharing } \\
\text { (EAI) - alpha }=.58\end{array}$ & & $.56^{* *}$ & $.74^{* *}$ & $.26^{* *}$ & $.38^{* *}$ \\
$\begin{array}{l}\text { Perspective taking } \\
\text { (EAI) - alpha }=.74\end{array}$ & & & $.83^{* *}$ & $.41^{* *}$ & $.58^{* *}$ \\
$\begin{array}{l}\text { Empathy Assessment } \\
\text { Index (EAI) }\end{array}$ & & & & $.38^{* *}$ & $.55^{* *}$ \\
$\begin{array}{l}\text { Contextual } \\
\text { understanding of } \\
\text { systemic barriers } \\
\text { (SEI) - alpha }=.88\end{array}$ & & & & & $.74^{* *}$ \\
\hline
\end{tabular}




\section{DISCUSSION}

The SEI measures two very important concepts for social work practice, general interpersonal empathy and social empathy. This research study is the first attempt to thoroughly explore the concept of social empathy. The results confirmed parts of Segal's (2011) original conceptualization of social empathy and allowed the researchers to finetune the components of the model (See Figure 2). Contextual understanding was supported as a key component of the model (See Table 4). The nine items focus on systemic barriers to social and economic equality with attention on beliefs regarding the marginalization of certain groups in society.

Figure 2

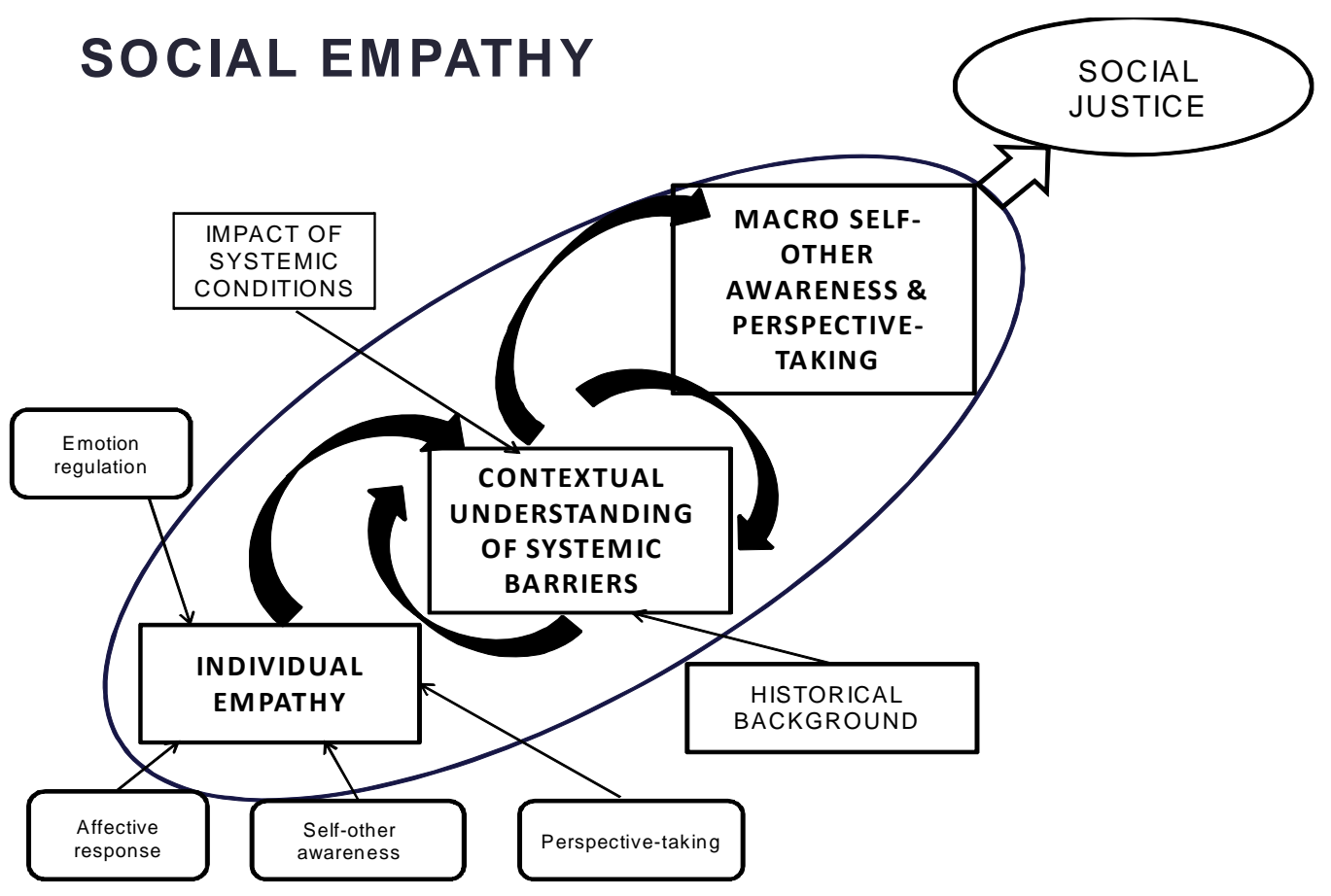

The social responsibility and social justice components were collapsed and the remaining nine items were re-conceptualized as macro aspects of self-other awareness (SOA) and perspective-taking (PT) (see Table 4). This finding makes sense considering PT and SOA are key components of interpersonal empathy as well. They appear to be equally important when applied at a macro level. Upon deeper analysis, it makes sense that social responsibility and social justice were not accurately conceptualized as part of the social empathy model. These two constructs are probably more precisely operationalized as action based outcomes. Table 4 lists the 18 remaining social empathy items. These 18 items as well as the 20 items from the EAI make up the 38-item SEI. 


\section{Table 4: $\quad$ Final Items for the SEI Components}

\section{CONTEXTUAL UNDERSTANDING OF SYSTEMIC BARRIERS}

I believe there are barriers in the United States' educational system that prevent some groups of people from having economic success.

I believe that people who face discrimination have added stress that negatively impacts their lives.

I believe people born into poverty have more barriers to achieving economic well-being than people who were not born into poverty

I believe adults who are poor deserve social assistance.

I believe government should protect the rights of minorities.

I believe the role of government is to act as a referee, making decisions that promote the quality of life and well-being of the people.

I think it is the right of all citizens to have their basic needs met.

I believe that by working together, people can change society to be more just and fair for everyone.

I think the government needs to be a part of leveling the playing field for people from different racial groups

\section{MACRO SOA/PT}

I have an interest in understanding why people are poor.

I can best understand people who are different from me by learning from them directly.

I feel it is important to understand the political perspectives of people I don't agree with.

I believe it is necessary to participate in community service.

I believe that each of us should participate in political activities.

I believe my actions will affect future generations.

I confront discrimination when I see it.

I am comfortable helping a person of a different race or ethnicity than my own.

I take action to help others even if it does not personally benefit me. 
The results of this study's analysis helped to refine the conceptualization of social empathy as a construct with three components: 1) interpersonal empathy (as measured by the EAI); 2) contextual understanding of systemic barriers; and 3) macro self-other awareness and perspective-taking (See Figure 2). The original SEI model was conceptually sound, but included some extraneous items and misidentified two components as social responsibility and social justice. In future research, a new data set will be used to perform a confirmatory factor analysis (CFA) using the new model. Such an analysis would allow for further exploration of the possibility that social empathy, as a higher-order latent construct, may explain the high correlation between the two factors in the current study. If the CFA results are acceptable, then researchers can test the hypothesis that social empathy predicts or is positively correlated with actions of social responsibility and social justice.

The current study is limited by the apparent homogeneity of the sample, which may be due to the sample having been drawn from social work education courses. While there were students from other academic majors in the courses, many of the students may have been influenced by a general "helping attitude" among those choosing the social work profession. To further test the psychometric properties of the SEI, a more heterogeneous sample should be sought in order to more fully reflect the range of perspectives and views on the social empathy constructs. This will also allow for further testing of the impact of social desirability given the self-report nature of the instrument.

In addition, future research is needed to explore how interpersonal empathy and social empathy are related and how interventions can effectively promote and build social empathy. With greater knowledge about social empathy and a tool to assess it, researchers will be able to determine whether social empathy leads to greater civic engagement and how it may be related to social responsibility. Such uses of the SEI can contribute to promoting the social justice goals of the social work profession.

\section{References}

Batson, C. D., Chang, J., Orr, R., \& Rowland, J. (2002). Empathy, attitudes, and action: Can feeling for a member of a stigmatized group motivate one to help the group? Personality and Social Psychology Bulletin, 28, 1655-1666.

Batson, C. D., Håkansson Eklund, J., Chermok, V. L., Hoyt, J. L., \& Ortiz, B. G. (2007). An additional antecedent of empathic concern: Valuing the welfare of the person in need. Journal of Personality and Social Psychology, 93, 65-74.

Busby, D. M., \& Gardner, B. C. (2008). How do I analyze thee? Let me count the ways: Considering empathy in couple relationships using self and partner ratings. Family Process, 47(2), 229-242.

Costello, A. B., \& Osborne, J. W. (2005). Best practices in exploratory factor analysis: Four recommendations for getting the most from your analysis. Practical Assessment, Research and Evaluation, 10(7), 1-9. 
Covell, C. N., Huss, M. T., \& Langhinrichsen-Rohling, J. (2007). Empathic deficits among male batterers: A multidimensional approach. Journal of Family Violence, 22, 165-174.

Curtner-Smith, M. E., Culp, A. M., Culp, R., Scheib, C., Owen, B. S., Tilley, A., Murphy, M., Parkman, L., \& Coleman, P. W. (2006). Mothers’ parenting and young economically disadvantaged children's relational and overt bullying. Journal of Child and Family Studies, 15(2), 181-193.

Decety, J. (2011). Dissecting the neural mechanisms mediating empathy. Emotion Review, 3(1), 92-108.

Decety, J., \& Moriguchi, Y. (2007). The empathic brain and its dysfunction in psychiatric populations: Implications for intervention across different clinical conditions. BioPsychoSocial Medicine, 1, 1-22.

de Waal, F. B. M. (2009). Putting altruism back into altruism: The evolution of empathy. Annual Review of Psychology, 59, 279-300.

de Weid, M., Branje, S. J. T., \& Meeus, W. H. J. (2007). Empathy and conflict resolution in friendship relations among adolescents. Aggressive Behavior, 33, 48-55.

Dovidio, J. F., Gaertner, S. L., \& Saguy, T. (2009). Commonality and the complexity of "we": Social attitudes and social change. Personality and Social Psychology Review, 13(1), 3-20.

Eisenberg, N., \& Eggum, N. D. (2009). Empathic responding: Sympathy and personal distress. In J. Decety \& W. Ickes (Eds.), The social neuroscience of empathy (pp. 7183). Cambridge, MA: MIT Press.

Eisenberg, N., \& Mussen, P. H. (1989). The roots of prosocial behavior in children. Cambridge, UK: Cambridge University Press.

Elsegood, K. J., \& Duff, S. C. (2010). Theory of mind in men who have sexually offended against children: A U.K. comparison study between child sex offenders and nonoffender controls. Sexual Abuse: A Journal of Research and Treatment, 22(1), 112-131.

Frank, R. H. (2001). Cooperation through emotional commitment. In R. M. Nesse (Ed.), Evolution and the capacity for commitment (pp. 57-76). New York: Russell Sage Foundation.

Galinsky, A. D., Ku, G., \& Wang, C. S. (2005). Perspective-taking and self-other overlap: Fostering social bonds and facilitating social coordination. Group Process and Intergroup Relations, 8(2), 109-124.

Gerdes, K. E. (2011). Empathy, sympathy and pity: $21^{\text {st }}$-Century definitions and implications for practice and research. Journal of Social Service Research, 37, 230241. 
Gerdes, K. E., Lietz, C., \& Segal, E. A. (2011). Measuring empathy in the $21^{\text {st }}$ century: The development of an empathy index rooted in social cognitive neuroscience and social justice. Social Work Research, 35(2), 83-93.

Gerdes, K. E., Segal, E. A., \& Lietz, C. (2010). Conceptualising and measuring empathy: The need for clarity and consistency. British Journal of Social Work, 40, 2326-2343. doi:10.1093/bjsw/bcq048.

Gibbons, S. B. (2011). Understanding empathy as a complex construct: A review of the literature. Clinical Social Work Journal, 39, 243-252. doi:10.1007/s10615-010-03052.

Gini, G., Albiero, P., Benelli, B., \& Altoe, G. (2007). Does empathy predict adolescents' bullying and defending behavior? Aggressive Behavior, 33, 467-476.

Gini, G., Albiero, P., Benelli, B., \& Altoe, G. (2008). Determinants of adolescents' active defending and passive bystanding behavior in bullying. Journal of Adolescence, 31, 93-105.

Glick, P. (2002). Sacrificial lambs dressed in wolves’ clothing: Envious prejudice, ideology, and the scapegoating of Jews. In L. S. Newman \& R. Erber (Eds.), Understanding genocide: The social psychology of the Holocaust (pp. 113-142). New York: Oxford University Press.

Glick, P. (2005). Choice of scapegoats. In J. F. Dovidio, P. Glick, \& L. A. Rudman (Eds.), On the nature of prejudice: 50 years after Allport (pp. 244-261). Malden, MA: Blackwell Publishing.

Glick, P. (2008). When neighbors blame neighbors: Scapegoating and the breakdown of ethnic relations. In V. M. Esses \& R. A. Vernon (Eds.), Explaining the breakdown of ethnic relations (pp. 123-146). Malden, MA: Blackwell Publishing.

Goldman, A. (2006). Simulating minds: The philosophy, psychology, and neuroscience of mindreading. Oxford, UK: Oxford University Press.

Henson, R. K., \& Roberts, J. K. (2006). Use of exploratory factor analysis in published research: Common errors and some comment on improved practice. Educational and Psychological Measurement, 66(3), 393-416.

Hoffman, M. L. (2000). Empathy and moral development: Implications for caring and justice. London: Cambridge University Press.

Hollan, D. (2012). Emerging issues in the cross-cultural study of empathy. Emotion Review, 4(1), 70-78.

Horton, P. (2011). School bullying and social and moral orders. (2011). Children \& Society, 25, 268-277.

Joliffe, D., \& Farrington, D. P. (2004). Empathy and offending: A systematic review and meta-analysis. Aggression and Violent Behavior, 9, 441-476. 
Konrath, S. H., O’Brien, E. H., \& Hsing, C. (2011). Changes in dispositional empathy in American college students over time: A meta-analysis. Personality and Social Psychology Review, 15(2), 180-198.

Lietz, C. A., Gerdes, K. E., Sun, F., Geiger, J. M., Wagaman, M. A., \& Segal, E. A. (2011). The Empathy Assessment Index (EAI): A confirmatory factor analysis of a multidimensional model of empathy. Journal of the Society for Social Work Research, 2(2), 104-124. doi:10.5243/jsswr.2011.6.

Mar, R. A. (2011). Deconstructing empathy. Emotion Review, 3, 113-114.

McMahon, S. D., Wernsman, J., \& Parnes, A. L. (2006). Understanding prosocial behavior: The impact of empathy and gender among African American adolescents. Journal of Adolescent Health, 39, 135-137.

Morrell, M. E. (2010). Empathy and democracy: Feeling, thinking, and deliberation. University Park, PA: Pennsylvania State University Press.

Obama, B. (2006). The audacity of hope. New York: Random House.

O’Connor, L. E., Berry, J. W., Weiss, J., \& Gilbert, P. (2002). Guilt, fear, submission, and empathy in depression. Journal of Affective Disorders, 71, 19-27.

Pett, M. A., Lackey, N. R., \& Sullivan, J. J. (2003). Making sense of factor analysis: The use of factor analysis for instrument development in health care research. Thousand Oaks, CA: Sage Publications.

Preston, S. D., \& de Waal, F. B. M. (2002). Empathy: Its ultimate and proximate bases. Behavioral and Brain Sciences, 25, 1-72.

Putnam, R. D. (1993). Making democracy work. Princeton, NJ: Princeton University Press.

Putnam, R. D. (1995). Bowling alone: America's declining social capital. Journal of Democracy, 6(1), 65-78.

Reich, R. (2004). http://greatergood.berkeley.edu/gg live/gg events videos/video/robert reich on soc ial justice and social empathy/

Rifkin, J. (2009). The empathic civilization: The race to global consciousness in a world in crisis. New York: Penguin Books.

Ritter, K., Dziobek, I., Preibler, S., Ruter, A., Vater, A., Fydrich, T., \& Roepke, S. (2011). Lack of empathy in patients with narcissistic personality disorder. Psychiatry Research, 187, 241-247. doi:10.1016/j.psychres.2010.09.013

Roan, L., Strong, B., Foss, P., Yager, M., Gehlbach, H., \& Metcalf, K. A. (2009). Social perspective taking. Technical Report 1259. Arlington, VA: U.S. Army Research Institute for the Behavioral and Social Sciences. 
Sartori, R., \& Pasini, M. (2007). Quality and quantity in test validity: How can we be sure that psychological tests measure what they have to? Quality and Quantity: International Journal of Methodology, 41, 359-374.

Segal, E. A. (2007). Social empathy: A tool to address the contradiction of working but still poor. Families in Society: The Journal of Contemporary Social Sciences, 88(3), 333-337.

Segal, E. A. (2008). Welfare reform: The need for social empathy. In I. Colby (Ed.), Comprehensive handbook of social work and social welfare, volume 4: Social policy and social practice (pp. 371-384). Hoboken, NJ: John Wiley \& Sons.

Segal, E. A. (2011). Social empathy: A model built on empathy, contextual understanding, and social responsibility that promotes social justice. Journal of Social Service Research, 37, 266-277.

Singer, T., \& Lamm, C. (2009). The social neuroscience of empathy. The Year in Cognitive Neuroscience 2009: Annual New York Academy of Science, 1156, 81-96.

Smetana, J. G., \& Killen, M. (2008). Moral cognition, emotions and neuroscience: An integrative developmental view. European Journal of Developmental Science, 2. Retrieved from http://www.v-r.de.ezproxy1.lib.asu.edu/en/redirect/t/2000001643/.

Sue, D. W. (2010). Microaggressions in everyday life: Race, gender, and sexual orientation. Hoboken, NJ: John Wiley \& Sons, Inc.

Todd, A. R., Bodenhausen, G. V., Richeson, J. A., \& Galinsky, A. D. (2011). Perspective taking combats automatic expressions of racial bias. Journal of Personality and Social Psychology, 100, 6, 1027-1042.

Toussaint, L., \& Webb, J. R. (2005). Gender differences in relationship between empathy and forgiveness. The Journal of Social Psychology, 145(6), 673-685.

Twenge, J. M. (2006). Generation me: Why today's young Americans are more confident, assertive, entitled - and more miserable than ever before. New York: Free Press.

Twenge, J. M., \& Campbell, W. K. (2009). The narcissism epidemic: Living in the age of entitlement. New York: Free Press.

Wagaman, M. A. (2011). Social empathy as a framework for adolescent empowerment. Journal of Social Service Research, 37, 278-293.

Walter, H. (2012). Social cognitive neuroscience of empathy: Concepts, circuits and genes. Emotion Review, 4(9), 9-17.

\section{Author note:}

Address correspondence to: Elizabeth A. Segal, Arizona State University, College of Public Programs, School of Social Work, 411 N. Central Ave, Suite 800, Phoenix, AZ 85004. Email: esegal@asu.edu 


\section{APPENDIX A}

\section{Summary Statistics and Subscale Assignment of Original Item Pool (38 items) of the Social Empathy Index (SEI)}

\begin{tabular}{|c|c|c|c|c|}
\hline Item Content & $M$ & $S D$ & Subscale & $\begin{array}{l}\text { Action as a result of } \\
\text { analysis }\end{array}$ \\
\hline $\begin{array}{l}\text { Q21) I believe there are barriers in the United States’ } \\
\text { educational system that prevent some groups of people } \\
\text { from having economic success. }\end{array}$ & 4.36 & 1.26 & $\begin{array}{l}\text { Contextual } \\
\text { understanding }\end{array}$ & Retained \\
\hline $\begin{array}{l}\text { Q22) I believe government should be expected to help } \\
\text { individuals. }\end{array}$ & 4.35 & 1.21 & $\begin{array}{l}\text { Social } \\
\text { responsibility }\end{array}$ & $\begin{array}{l}\text { Eliminated in first } \\
\text { round of item reduction }\end{array}$ \\
\hline Q23) I seek to understand social problems. & 4.46 & 1.24 & $\begin{array}{l}\text { Contextual } \\
\text { understanding }\end{array}$ & $\begin{array}{l}\text { Eliminated in first } \\
\text { round of item reduction }\end{array}$ \\
\hline Q24) I believe my actions will affect future generations. & 4.63 & 1.20 & Social justice & Retained \\
\hline $\begin{array}{l}\text { Q25) I believe adults who are poor deserve social } \\
\text { assistance. }\end{array}$ & 4.19 & 1.21 & $\begin{array}{l}\text { Social } \\
\text { responsibility }\end{array}$ & Retained \\
\hline $\begin{array}{l}\text { Q26) As members of society, I believe we should help } \\
\text { people who are worse off than ourselves. }\end{array}$ & 4.67 & 1.19 & Social justice & $\begin{array}{l}\text { Eliminated in first } \\
\text { round of item reduction }\end{array}$ \\
\hline $\begin{array}{l}\text { Q27) I believe people are rich because they worked hard. } \\
\text { (reverse scored) }\end{array}$ & 3.50 & 1.05 & $\begin{array}{l}\text { Contextual } \\
\text { understanding }\end{array}$ & $\begin{array}{l}\text { Eliminated in first } \\
\text { round of item reduction }\end{array}$ \\
\hline Q28) I confront discrimination when I see it. & 3.79 & 1.17 & Social justice & Retained \\
\hline $\begin{array}{l}\text { Q29) I believe success in life depends on where you } \\
\text { were born. }\end{array}$ & 3.05 & 1.12 & $\begin{array}{l}\text { Contextual } \\
\text { understanding }\end{array}$ & $\begin{array}{l}\text { Eliminated in first } \\
\text { round of item reduction }\end{array}$ \\
\hline Q30) I think society should help out adults in need. & 4.23 & 1.24 & $\begin{array}{l}\text { Social } \\
\text { responsibility }\end{array}$ & $\begin{array}{l}\text { Eliminated in first } \\
\text { round of item reduction }\end{array}$ \\
\hline $\begin{array}{l}\text { Q31) If a person is homeless, I believe it is the result of } \\
\text { bad personal choices. (reverse scored) }\end{array}$ & 4.03 & 0.92 & $\begin{array}{l}\text { Contextual } \\
\text { understanding }\end{array}$ & $\begin{array}{l}\text { Eliminated in first } \\
\text { round of item reduction }\end{array}$ \\
\hline $\begin{array}{l}\text { Q32) When I hear a prejudiced joke or comment, it } \\
\text { bothers me. }\end{array}$ & 4.05 & 1.41 & Social justice & $\begin{array}{l}\text { Eliminated in first } \\
\text { round of item reduction }\end{array}$ \\
\hline $\begin{array}{l}\text { Q33) I have an interest in understanding why people are } \\
\text { poor. }\end{array}$ & 4.00 & 1.36 & $\begin{array}{l}\text { Contextual } \\
\text { understanding }\end{array}$ & Retained \\
\hline $\begin{array}{l}\text { Q34) I believe it is necessary to participate in } \\
\text { community service. }\end{array}$ & 4.71 & 1.20 & $\begin{array}{l}\text { Social } \\
\text { responsibility }\end{array}$ & Retained \\
\hline $\begin{array}{l}\text { Q35) I struggle to speak up for someone or about an } \\
\text { issue if what I say might make others angry or unhappy. } \\
\text { (reverse scored) }\end{array}$ & 4.16 & 1.09 & Social justice & $\begin{array}{l}\text { Eliminated in first } \\
\text { round of item reduction }\end{array}$ \\
\hline $\begin{array}{l}\text { Q36) I believe people get opportunities because they } \\
\text { know the right people. }\end{array}$ & 3.69 & 0.94 & $\begin{array}{l}\text { Contextual } \\
\text { understanding }\end{array}$ & $\begin{array}{l}\text { Eliminated in first } \\
\text { round of item reduction }\end{array}$ \\
\hline Q37) I think paying taxes is part of being a good citizen. & 4.29 & 1.27 & $\begin{array}{l}\text { Social } \\
\text { responsibility }\end{array}$ & $\begin{array}{l}\text { Eliminated after first } \\
\text { EFA }\end{array}$ \\
\hline $\begin{array}{l}\text { Q38) I believe government should get involved in } \\
\text { addressing social problems. }\end{array}$ & 4.55 & 1.23 & $\begin{array}{l}\text { Social } \\
\text { responsibility }\end{array}$ & $\begin{array}{l}\text { Eliminated in first round of } \\
\text { item reduction }\end{array}$ \\
\hline $\begin{array}{l}\text { Q39) I believe that people who face discrimination have } \\
\text { added stress that negatively impacts their lives. }\end{array}$ & 4.75 & 1.24 & $\begin{array}{l}\text { Contextual } \\
\text { understanding }\end{array}$ & Retained \\
\hline Q40) I am comfortable helping a person of a different & 5.46 & 0.96 & Social justice & Retained \\
\hline
\end{tabular}




\begin{tabular}{|c|c|c|c|c|}
\hline Q41) I believe people should vote in public elections. & 5.17 & 1.17 & $\begin{array}{l}\text { Social } \\
\text { responsibility }\end{array}$ & Eliminated after first EFA \\
\hline $\begin{array}{l}\text { Q42) I take action to help others even if it does not } \\
\text { personally benefit me. }\end{array}$ & 4.64 & 1.12 & Social justice & Retained \\
\hline Q43) I think society should help out families in need. & 4.80 & 1.15 & $\begin{array}{l}\text { Social } \\
\text { responsibility }\end{array}$ & $\begin{array}{l}\text { Eliminated in first round of } \\
\text { item reduction }\end{array}$ \\
\hline $\begin{array}{l}\text { Q44) I believe the rich get richer while the poor get } \\
\text { poorer. }\end{array}$ & 4.21 & 1.30 & $\begin{array}{l}\text { Contextual } \\
\text { understanding }\end{array}$ & $\begin{array}{l}\text { Eliminated in first round of } \\
\text { item reduction }\end{array}$ \\
\hline $\begin{array}{l}\text { Q45) I can best understand people who are different } \\
\text { from me by learning from them directly. }\end{array}$ & 4.80 & 1.08 & $\begin{array}{l}\text { Contextual } \\
\text { understanding }\end{array}$ & Retained \\
\hline $\begin{array}{l}\text { Q46) I think volunteerism is a duty for us as members of } \\
\text { society. }\end{array}$ & 4.65 & 1.24 & $\begin{array}{l}\text { Social } \\
\text { responsibility }\end{array}$ & $\begin{array}{l}\text { Eliminated in first round of } \\
\text { item reduction }\end{array}$ \\
\hline $\begin{array}{l}\text { Q47) I believe government should protect the rights of } \\
\text { minorities. }\end{array}$ & 4.98 & 1.20 & Social justice & Retained \\
\hline $\begin{array}{l}\text { Q48) I believe that each of us should participate in } \\
\text { political activities. }\end{array}$ & 4.19 & 1.28 & $\begin{array}{l}\text { Social } \\
\text { responsibility }\end{array}$ & Retained \\
\hline $\begin{array}{l}\text { Q49) I believe people born into poverty have more } \\
\text { barriers to achieving economic well-being than people } \\
\text { who were not born into poverty. }\end{array}$ & 4.82 & 1.14 & $\begin{array}{l}\text { Contextual } \\
\text { understanding }\end{array}$ & Retained \\
\hline $\begin{array}{l}\text { Q50) I feel it is important to understand the political } \\
\text { perspectives of people I don't agree with. }\end{array}$ & 4.48 & 1.15 & $\begin{array}{l}\text { Contextual } \\
\text { understanding }\end{array}$ & Retained \\
\hline $\begin{array}{l}\text { Q51) I believe it is important for me to contribute to my } \\
\text { community and society. }\end{array}$ & 4.91 & 1.20 & $\begin{array}{l}\text { Social } \\
\text { responsibility }\end{array}$ & $\begin{array}{l}\text { Eliminated in first round of } \\
\text { item reduction }\end{array}$ \\
\hline $\begin{array}{l}\text { Q52) I think it is the right of all citizens to have their } \\
\text { basic needs met. }\end{array}$ & 5.05 & 1.12 & Social justice & Retained \\
\hline $\begin{array}{l}\text { Q53) I believe the role of government is to act as a } \\
\text { referee, making decisions that promote the quality of life } \\
\text { and well-being of the people. }\end{array}$ & 4.49 & 1.25 & $\begin{array}{l}\text { Social } \\
\text { responsibility }\end{array}$ & Retained \\
\hline $\begin{array}{l}\text { Q54) I believe that by working together, people can } \\
\text { change society to be more just and fair for everyone. }\end{array}$ & 5.00 & 1.05 & Social justice & Retained \\
\hline $\begin{array}{l}\text { Q55) I think the government needs to be a part of } \\
\text { leveling the playing field for people from different racial } \\
\text { groups. }\end{array}$ & 4.49 & 1.28 & $\begin{array}{l}\text { Contextual } \\
\text { understanding }\end{array}$ & Retained \\
\hline $\begin{array}{l}\text { Q56) I believe all people are entitled to the same civil } \\
\text { rights and opportunities. }\end{array}$ & 5.31 & 1.07 & Social justice & Eliminated after first EFA \\
\hline $\begin{array}{l}\text { Q57) I believe that making society fair benefits } \\
\text { everyone, not just people who are poor or discriminated } \\
\text { against. }\end{array}$ & 5.03 & 1.13 & Social justice & $\begin{array}{l}\text { Eliminated in first round of } \\
\text { item reduction }\end{array}$ \\
\hline $\begin{array}{l}\text { Q58) I think it is my responsibility to help those who are } \\
\text { in need. }\end{array}$ & 4.73 & 1.24 & $\begin{array}{l}\text { Social } \\
\text { responsibility }\end{array}$ & $\begin{array}{l}\text { Eliminated in first round of } \\
\text { item reduction }\end{array}$ \\
\hline
\end{tabular}

